\title{
The other voice of early modern science
}

\author{
Judith Zinsser (ed): Emilie du Châtelet, Selected philosophical \\ and scientific writings. University of Chicago press, Chicago, 2009, \\ xxviii + 424 pp, US\$ 35.00 PB
}

\section{Massimo Mazzotti}

Published online: 12 August 2010

(C) The Author(s) 2010. This article is published with open access at Springerlink.com

Until fairly recently, historical narratives of the scientific revolution and the Enlightenment sciences contained only sparse and anecdotal references to women. The widespread assumption was that their contribution to the making of modern science had been, overall, negligible. One reason for this belief was the limited visibility, from a twentieth-century standpoint, of early modern female philosophers and mathematicians. Where traces of women's scientific activity could be found, these were often classified as 'mere' forms of popularization. It was well known, for example, that in the eighteenth century some women had translated scientific texts, facilitated their circulation and discussion in various European settings, and more generally acted as cultural mediators. It was also clear that, in some cases, women had contributed to the scientific achievements of male members of their family, most typically through carrying out lengthy calculations, executing drawings, and performing other low-profile, mostly unacknowledged tasks. These activities, it was argued, were nevertheless marginal to the development of modern science.

The last few years have seen a remarkable rise of the interest in the role of women in early modern science and the beginning of a profound re-interpretation of their contribution. In part, this new scholarship originates from the emergence of a new image of science, one that does not operate an a priori demarcation between the sphere of knowledge production and that of communication, popularization, and discussion, but rather considers them as aspects of a complex historical process of knowledge-making and legitimation. Coordinating a salon or translating and commenting on a scientific text are best understood as active interventions that contribute to the shaping of scientific knowledge, rather than as attempts to 'diffuse' some pre-packaged set of notions. Also relevant for the new perception of the role of women in early modern science is the progressive rediscovery of texts that reveal

\footnotetext{
M. Mazzotti $(\bowtie)$

Department of History, University of California, 2209 Dwinelle Hall, Berkeley, CA 94720-2550, USA

e-mail: mazzotti@berkeley.edu
} 
how some of them had entered as actors the eminently masculine spaces of knowledge production: experimenting, writing treatises, participating in scholarly debates, and even, in a few cases, teaching at institutions of higher education.

Emilie du Châtelet (1706-1749) is a case in point. A member of the French high aristocracy, she went down in history mostly for her sentimental life, and especially her long-lasting relationship with Voltaire. And yet, she was a competent natural philosopher who debated and wrote on some of the major scientific issues of her time. She also carried out the first-excellent-French translation of Isaac Newton's notoriously difficult Principia Mathematica. The book edited by Judith Zinsser offers a selection and translation of texts, published and unpublished, from Du Châtelet's varied production. The Discourse on Happiness is probably her best known work and is presented here in its entirety. Published posthumously in 1779, this is an original variation on a popular eighteenth-century theme in which the author emphasizes, among other things, the "love of study" as one of the sources of happiness for women, as they are excluded, "by definition, from every kind of glory" (357). Moral considerations were also at the basis of her translation of excerpts from Bernard Mandeville's The Fable of the Bees, whose preface appears in this collection. In introducing what she saw as "the best book of ethics ever written", Du Châtelet reflects on the key role of translators, the "entrepreneurs [négociants] of the Republic of Letters", and on the "prejudice that excludes us [women] so universally from the sciences" (46-50). As for her contributions to natural philosophy, the reader will find a selection of passages from an academic dissertation on the nature and propagation of fire, first published in 1739, where Du Châtelet distances herself from Voltaire's orthodox Newtonian position. Her independence of thinking emerges clearly in the sections from the Institutions de physique (here rendered as Foundations of Physics), a tract published in 1740, where she attempts to provide Newtonian mechanics with those sound metaphysical foundations that, according to many continental philosophers, it lacked. Du Châtelet argued that the best foundations would be provided by the metaphysics of Leibniz and Wolff. This tract reveals her philosophical and mathematical competence, as does her own translation of Newton's Principia Mathematica-part of her commentary to Newton's text is included here. This translation, completed just before Du Châtelet's death at childbirth in 1749, appeared posthumously in 1759 and was widely acclaimed by the French literary world. Finally, the selection includes a sample from her Examinations of the Bible, a long study of the Old and New Testaments in which Du Châtelet engaged both with the biblical text and with authoritative contemporary interpreters such as the Benedictine monk Augustine Calmet. Du Chatelet's main target is the vengeful, inscrutable God of the Old Testament. Her rationalistic Leibnizian inclinations made her argue for a rather different image of deity and of the order of creation. Like many other unorthodox texts of religious argument of the period, Du Châtelet's reflections were not prepared for publication but circulated widely in various manuscript copies.

Readers of this volume will be certainly intrigued by various aspects of $\mathrm{Du}$ Châtelet's life and work. It might come as a surprise to some, but she was recognized by many contemporaries as a legitimate and credible member of the republic of letters. The degree of recognition was even greater for other learned women who, in the same years, joined academies and universities in northern Italy. 
These femmes savants or, as they were called in Italy, filosofesse (women philosophers) were indeed a well-known phenomenon that seems to have peaked in the first half of the eighteenth century, and their texts were often published under the patronage of prestigious individuals and institutions. The current rediscovery of their work is, one realizes, an attempt to rescue them from the oblivion into which they fell at the turn of the nineteenth century. Interestingly, most of the texts published in this book had always been available to historians. Nevertheless, they were not perceived as relevant and had gradually slipped out of sight. It is telling that the only text that has been reprinted and read during the last two centuries is the Discourse on Happiness, as it was considered emblematic of its author's libertine and immoral inclinations. Readers will also realize, of course, the resistance met by Du Châtelet in her attempt to construct a scholarly reputation for herself, especially as a mathematician. It should be noted, incidentally, that the terms femmes savants and filosofesse were ambiguous in their eighteenth-century usage, as they could be deployed ironically as well, and were often associated with images of luxurious, immoral, and overly powerful women.

In her introduction, Judith Zinsser, who is the author of a very well-written and researched biography of $\mathrm{Du}$ Châtelet, manages to give a sense of her complex interactions with the republic of letters and of the ways in which she tried to integrate her various social roles. Zinsser also provides the essential coordinates to understand the meaning of the selected texts, which are accompanied, cleverly, by a few letters that help the non-specialist to put them into context. Overall, the critical apparatus will serve well the general audience, in spite of a few imprecisions and the occasional puzzling claim-e.g. 'natural philosophy' is 'a phrase coined in seventeenth-century England' (105); Du Châtelet 'counted among the twenty or so eighteenth-century men and women who understood this advanced mathematics [Newton's Principia]' (251). As for the texts selected, they represent well the breadth of Du Châtelet's intellectual interests and writing styles. There is no direct evidence, however, of her mathematical competence-which is of no surprise as publishers are notoriously wary of inserting formulas in their books. Du Châtelet is writing at a time when scientific books 'for ladies' took out mathematics because of women's alleged mathematical inability and more generally their little inclination for rational thinking. In fact, during her life, similar beliefs began to be naturalized through new theories of the brain and cognition. In the end, Du Châtelet and the other learned women of that period would fail to break the increasingly powerful association of masculinity and mathematics. Showing some of her brilliant renderings of difficult passages of the Principia, or samples of her use of 'mixed mathematics', would have been therefore particularly meaningful.

Zinsser's well-crafted collection comes at a crucial moment in the study of the role of women in early modern science and makes an important contribution to itnot least as an invaluable didactic tool. Finally, the other voice of early modern science is beginning to be heard.

Open Access This article is distributed under the terms of the Creative Commons Attribution Noncommercial License which permits any noncommercial use, distribution, and reproduction in any medium, provided the original author(s) and source are credited. 